IZA DP No. 7472

Joint Custody in the Italian Courts

Guido de Blasio

Daniela Vuri

June 2013

Forschungsinstitut zur Zukunft der Arbeit Institute for the Study of Labor 


\title{
Joint Custody in the Italian Courts
}

\author{
Guido de Blasio
}

Bank of Italy

\author{
Daniela Vuri \\ University of Rome "Tor Vergata" \\ and IZA
}

\section{Discussion Paper No. 7472 \\ June 2013}

\author{
IZA \\ P.O. Box 7240 \\ 53072 Bonn \\ Germany \\ Phone: +49-228-3894-0 \\ Fax: +49-228-3894-180 \\ E-mail: iza@iza.org
}

Any opinions expressed here are those of the author(s) and not those of IZA. Research published in this series may include views on policy, but the institute itself takes no institutional policy positions. The IZA research network is committed to the IZA Guiding Principles of Research Integrity.

The Institute for the Study of Labor (IZA) in Bonn is a local and virtual international research center and a place of communication between science, politics and business. IZA is an independent nonprofit organization supported by Deutsche Post Foundation. The center is associated with the University of Bonn and offers a stimulating research environment through its international network, workshops and conferences, data service, project support, research visits and doctoral program. IZA engages in (i) original and internationally competitive research in all fields of labor economics, (ii) development of policy concepts, and (iii) dissemination of research results and concepts to the interested public.

IZA Discussion Papers often represent preliminary work and are circulated to encourage discussion. Citation of such a paper should account for its provisional character. A revised version may be available directly from the author. 


\section{ABSTRACT}

\section{Joint Custody in the Italian Courts}

This paper studies the impact of the introduction of joint custody in Italy (Law 54/2006) on judiciary outcomes. As to the formal (legal) assignment of joint custody, the reform envisaged very little judge discretion. With reference to the substance of the custody (the amount of time each parent spends with the child and the money involved in post-dissolution arrangements), the law established new principles while leaving plenty of implementation power to the judges. Our results - based on court data that covers the universe of separations from 2000 to 2010 - document that the law was only cosmetically applied by the judges. Compared to the pre-reform regime, the share of sole legal custody assignments to the mother drastically decreased. However, court implementation washed out the new principles: the provisions of the law related to the financial post-separation arrangements remained unapplied. This suggests that the main innovative aspect of the law - the possibility for a child to spend an adequate amount of time with both parents - was also left unchanged with respect to the previous regime of sole maternal custody. As joint effect of the introduction of the law and the little degree to which the new principles have been translated into actual verdicts, there was a surge in litigiousness among separating spouses and judicial inefficiency. Moreover, the incentives for a female partner to apply for a separation raised. The paper discusses a possible rationale for the findings and some related policy remedies. As for the former, the evidence we present can be explained by the adoption of gender-biased judiciary practices. As for the latter, our results suggest that a restatement of the law, to define a narrowed grid of prescriptions that constrain judge discretion, could be an effective corrective action.

JEL Classification: K36, J12, J16

Keywords: joint custody, separation, judiciary outcomes, difference-in-differences, Italy

Corresponding author:

Daniela Vuri

University of Rome Tor Vergata

Faculty of Economics

Via Columbia 2

00133 Roma

Italy

E-mail: daniela.vuri@uniroma2.it

\footnotetext{
* We thank Andrea Filippone and Federico Perali for helpful comments. The views and the opinions expressed in this paper are those of the authors and do not necessarily correspond to those of the Institutions they are affiliated with. The data have been obtained by the Italian National Institute of Statistics (ISTAT) under the research protocol signed by ISTAT and Department of Economics and Finance of the University of Rome "Tor Vergata" for the project "The consequences of joint custody on separating and divorcing couples". We are deeply grateful to Giancarlo Gualtieri from ISTAT for the help with the data.
} 
If we want things to stay as they are, things will have to change Giuseppe Tomasi di Lampedusa, The Leopard

\section{Introduction}

Joint custody is widely applied around the world. A consensus has emerged that this type of arrangement is the one that better serves the wellbeing of both the children and the parents involved in the dissolution of their family. For instance, Bauserman (2002) documents that joint custody favors children behavioral and emotional adjustments; Teng Wah (2009) shows that it allows children to be better off in terms of higher number of years of education and increased probability of high school graduation; Nunley and Seals (2011) argue that the prospects of shared child custody affect within-marriage time allocation by inducing mothers to work more in the market and fathers to work more at home; Allen et al. (2011) suggest that the arrangement increases the fathers' willingness to pay child support. Beyond the positive effects on the children and the parents involved, joint custody seems also to provide additional advantages for the society at large. Joint custody increases marriage rates (see: Brinig and Buckley, 1998; and Halla, 2013); decreases the cost of litigation, enabling more parents to divorce by mutual consent (Halla and Höltz, 2007); and boosts female employment and birth rates (Böheim et al, 2012).

With a remarkable delay compared to other EU countries, in 2006 Italy's Parliament approved a law (Law 54/2006) that introduced joint custody. The law states that it is a right of the child to have a balanced and lasting relation with both parents. This statement revolutionized the subject, as pre-reform arrangements envisaged sole maternal custody while fathers' visitation rights were extremely limited. At the same time, the reform innovated on a number of post-separation financial provisions (related to child support and the destination of the family house) with the aim of achieving the objective set forth by the law, i.e. granting the child a sound relation with both parents.

This paper studies the impact of the introduction of joint custody in Italy on judiciary outcomes. It exploits a unique data set of individual applications to Italian courts and the corresponding judgments. Data are collected by the offices that support the work of the judges (Cancellerie) for the entire population of separating couples from 2000 to 2010. Therefore, they cover many years before and after the introduction of the law in March 2006 and allow us to identify the impact of the reform over the medium-term. The data permit us to study a number of judiciary outcomes, mostly related to the post-separation financial arrangements, such as the assignment of family house and the amount of child support. An important part of the judgment, that is, the 
amount of time that each parent is allowed to spend with the children, is unfortunately not collected. Nevertheless, as the reform prescribes that custodial length goes hand in hands with child support, we are able to infer something on visitation durations by looking at financial outcomes. In addition to the main outcomes that the Law 54/2006 aimed to change, we consider other possible outcomes such as alimonies, which are not directly touched by the reform but nevertheless are part of the judge decision, and the gender composition of the applicants for separations, which might reveal the change in the incentives for the separating parties involved due to the introduction of the joint custody.

In order to analyze the consequences of joint custody over socio-economic outcomes, judicial outcomes are of utmost importance. Typically, in custody regulation judge discretion is maximized. As argued by Maidment (1984), Mason (1994), and Maccoby and Mnookin (1997), the key principle, which inspires many national regulations, is that of the 'best interest of the child'. This principle is quite vague: as indicated by Böheim et al (2012, p. 2) "it gives excessive discretion to judges to impose their own value judgment about which parent might better serve the child's interests." It also has to be underlined that the decisions related to custody are very often linked to deep feelings with regard to the role of women in child rearing and, more generally, the gender divide (see: Barlett and Stack, 1986). Therefore, cultural and ideological reasons might also matter, to the extent that the judiciary is not shield from those influences. Gennaioli and Shleifer (2008) provide a model of judicial discretion. In their analysis, discretion is due to both judges' policy preferences and their aversion to reversal on appeal (this latter motive induces the judges to replicates the previous courts decisions that survived from being overruled by appellate courts).

Because of judge discretion, law principles might only partially results in actual court decisions. ${ }^{1}$ The role of the wedge between the laws and the effective judicial enforcement of the rules is very well recognized in the studies of law and economics (see, for instance, Posner, 2005). Some studies have also suggested the channels through which the judges' policy preferences enter into the picture. Donohue and Siegelman (1991) show that anti-discrimination rules are variously applied depending on the strength of the labor market; by the same token, Ichino et al (2002) find that in firing dispute resolutions, Italy's judges are biased by the current conditions of the labor market (namely, a pro-worker decision is more likely in places where unemployment is higher). To explain the estimated different amounts of bias between Northern and Southern courts, Ichino et al (2002) explicitly refer to the political orientation of the judges. ${ }^{2}$

\footnotetext{
${ }^{1}$ If this is the case, then the possibility of inferring from a reform in child-custody principles its implications on socio-economic outcomes is clearly impaired. This is a serious shortcoming for the empirical studies that try to identify the effects of joint custody by comparing states with different law provisions in place, or overtime changes in law, without checking to what extent judicial outcomes follows the variations in regulations. Indeed, the search for exogenous source of variations has led many papers to exploit precisely this route.

2 The pervasiveness of a political bias in Italy's judiciary is currently a hot topic in Italy's political debate.
} 
Our findings show that the Law 54/2006 found only little implementation in courts. Note that the reform envisaged very little judge discretion as to the formal (legal) assignment of joint custody. On the contrary, with reference to the substance of the custody (the amount of time each parent spends with the child and the money involved in post-dissolution arrangements), the law established the new principles while leaving plenty of implementation power to the judges. Our results document that compared to the pre-reform regime, the share of sole custody legal assignments to the mother drastically decreased. However, the provisions of the law related to financial post-separation arrangements remained unapplied. We also find that as joint effect of the introduction of the law and the little degree to which the new principles have been translated into actual court decisions there was a surge in litigiousness among separating spouses and some evidence of an increase in judicial inefficiency. Finally, we investigate whether the behavior of the judiciary with respect to the application of the Law 54/2006 can be related to its overall inefficiency, as extensively documented in other studies (see, for instance, Bianco et al, 2007). We find that this is unlikely to be the case and we suggest that our empirical evidence might be explained by gender-biased judiciary practices (possibly compounded with forms of herd behavior, as Gennaioli and Shleifer (2008) have suggested). ${ }^{3}$

The paper is structured as follows. Section II provides a description of the Law 54/2006. Section III describes the data and the variables used throughout the paper, such as the judiciary outcomes under study. Section IV sketches the difference-in-differences identification strategy we employ. The results are presented in Section V. Section VI concludes offering an interpretation of the findings and some policy suggestions.

\section{Law Provisions}

Despite the strong opposition of the Catholic Church and some political parties, the unilateral divorce was introduced in Italy in December 1970 (Law n. 898 - "Disciplina dei casi di scioglimento del matrimonio"). As for child custody, sole custody was envisaged. In 1974, the opponents of divorce promoted a referendum to abolish the divorce law introduced 4 years earlier but they were defeated. In the following years, the divorce law went through only minor changes. ${ }^{4}$ We have to wait several decades before a big change in a divorce

\footnotetext{
3 Our study is the first one that documents what is going on in the courts following the introduction of the Law 54/2006. Note however that the fact that the law has been only cosmetically implemented by the judges, even though inferred from case-studies, is already in the public domain (see: http://italia.panorama.it/Separazioni-e-affido-padri-scippati and http://www.europarl.europa.eu/sides/getDoc.do?pubRef=-//EP//TEXT+WQ+E-2011-000860+0+DOC+XML+V0//EN).

${ }_{4}^{4}$ For instance, Law 74/1987 was aimed to shorten the time needed to have a divorce judgment by allowing the judge to give a decree nisi without necessarily issuing at the same time a money judgment and/or deciding upon child custody.
} 
related issue took place, namely the Law 54/2006, which changed the standard arrangement from sole custody to joint custody of dependent children.

The Law 54/2006, known as the "Joint Custody" law, was passed by the Italian Parliament in February 2006 and became effective in March 2006. It recognizes (art. 1) "the right for a child to have balanced and lasting relations with both parents; to receive cure, education and upbringing from both of them; to keep relationships with ascendants and relatives from both parental branches."5 This provision, which intends to discipline both legal custody and physical custody, reflects the statement of the United Nation Convention on the Rights of the Child, adopted on 20 November 1989. Compared with the previous regulation - according to which "the judge decides which parent has custody of the child" - the innovation introduced with the Law 54/2006 is of great relevance. Prior to the reform, legal custody was assigned to mothers in the overwhelming majority of the cases. ${ }^{6}$ As to physical custody, the relation between a child and her/his father was limited to few weekly hours, one or two week ends every months, a couple of weeks during the summer.

The introduction of the law can be considered as largely unexpected. This is not because a political consensus for the new framework suddenly materialized, so to surprise private agents, but for the reason that the reform, surrounded by strong opposition, was stalled for very long: the delay in the approval of the draft of the law caused high uncertainty on whether and when the law would have been finally signed. A first draft of the joint custody law was submitted to the Parliament as early as 1994. Then, for the two next parliamentary terms the draft remained unsigned. Finally, it was endorsed in February 2006, amidst strong opposition from a number of congresspersons (mostly, from leftist parties): the bill was signed in an overnight parliamentary meeting and the law passed without unanimity. ${ }^{7}$

The new law provisions can be summarized as follows.

i) The formal aspects. As standard rule, the judge has to assign joint legal custody to parents; where very specific circumstances occur which make sole custody preferable in the child's interest, they have to be explicitly documented. This means that the judge's discretion to assign sole legal custody is quite reduced.

\footnotetext{
5 In this paragraph we only list the elements of the Law 56/2006 related to our empirical investigation. For a more in-depth description of the law see Maglietta (2006) and Gaglione and Malfettani (2008).

${ }^{6}$ In our data, before the introduction of the joint custody law, the fraction of sole maternal custody over the total separations with minors was just below $85 \%$ (see: Section III).

${ }^{7}$ Maglietta (2006) provides an historical account of the reasons behind the opposition to the approval of the law on joint custody. He mentions both vested interests, related to the fact that the custody implies relevant wealth effects, and ideological reasons, related to the view on the role of women in society.
} 
ii) The substantive aspects. The legal assignment of joint custody is followed by two types of decisions referring to the substance of the custody. First, the time spent by each parent with the child must be determined such that the objective set forth by the law (i.e. that the child has balanced and lasting relations with both parents) is actually implemented. Basically, fathers are allowed to spend more time with children. Second, post-separation financial provisions must also be defined consistently with the aim of the law. In particular, the law provision according to which both parents have joint responsibilities to provide care, education and upbringing goes hand in hand with shared financial responsibility for the two parents, taking into account "the financial needs of the child, the respective income and wealth positions of the parents, the actual time spent with the child and the extent of domestic care provided by each parent." Note that for the provisions related to the substance of the custody the judge has huge discretion on how to apply the rules to the facts of each case. As we show in Sect. V, this flexibility is going to be crucial for the outcomes of the reform in courts' decisions.

As for financial provisions, two aspects have been substantially revised in Law 54/2006:

a) The family house is assigned by the judge to one of the separating spouses by taking into account the "interest of the children" (paragraph 2 of the Statute). This provides a clear departure from the past, as the house was always assigned to the custodian parent, that is, the mother in the overwhelming majority of the cases (in our data $69.4 \%$ of mothers kept the family house in the pre-reform period). ${ }^{8}$ Note that the decision on who keeps the family house is very relevant, as the wealth invested in the house represents almost $60 \%$ of the net family wealth (Bank of Italy, 2011) and the expenditures related to housing amount to $25 \%$ of the income of the family of the tenant (Bank of Italy, 2012).

b) The law introduces a change from indirect support (non-targeted financial support) from the non-custodial parent (usually the father) to the custodial parent (usually the mother), to direct support, through which both parents are bound to provide financial support to the child(ren), each for some types of goods and services. This is meant to address the agency-cost problem arising from the fact that, in case of non-targeted financial support (see: Mnookin and Kornhauser,1979, Weiss and Willis, 1985), the non-custodial parent cannot perfectly monitor how his financial contributions are spent, and therefore assumes that some money will be misspent (in turn, the assumption of misspending weakens the incentives for the non-custodial parent to contribute to the support of the child(ren)).

\footnotetext{
${ }^{8}$ As reported by Gaglione and Malfettani (2008) in case of complete sharing of the time spent with the child, the judge is requested to make a decision among the following alternatives: a) house to the parent economically more vulnerable; $b$ ) house to the parent who is considered more suitable to live with the child(ren), c) house unassigned: both the parents will alternately live with the child(ren) in the family house.
} 
Other aspects of the post-separation financial provisions were left unchanged. Among those, note that alimonies were not part of the bill approved on March 2006. They are regulated by the art. 5 of the Law $898 / 1970$, which was not modified by the Law 54/2006.

\section{Data and Empirical Issues}

Our analysis uses unique, high-quality administrative data drawn from all the separations and divorces proceedings registered at the 165 civil courts in Italy between 2000 and 2010.9 The questionnaires are directly filled at the courts and sent to the Italian National Institute of Statistics (ISTAT) every three months.

The data contain information on:

a. the features of the legal proceeding: when the proceeding started (data del procedimento), the date of the decision (data del provvedimento), the location of the court, the legal grounds on which the separation started and then is conferred (mutual consent vs no agreement), the spouse who filled the application for separation, whether any party hired a lawyer;

b. post-dissolution measures: obligations of providing alimony and child support, their amounts, the right to keep the family house;

c. child demographics: gender, age and legal custody arrangement of each child living at home;

d. other demographics: date of marriage, celebration rite (civil vs religious), prenuptial agreement (joint or disjoint management of the family wealth), spouses' demographics (date and place of birth, residence, nationality, marital status before the current marriage, education, employment status, occupation, sector of activity).

It is important to note that the information in $a, b$ and $c$ are collected directly from the proceeding papers and therefore are very reliable especially for what concerns the economic aspects. The socio-demographic information are asked to the splitting spouses or to their lawyers, if not contained in the proceeding papers.

In the empirical section below we estimate the causal impact of the introduction of the Law 54/2006 focusing on 3 types of outcomes:

A) Expected outcomes. These are the outcomes for which the law prescribes a change with respect to the past. As explained above, we expect judicial decisions to follow the new rules both with reference to the legal

9 The questionnaire is named ISTAT M.253 (ISTAT M.252 for divorces). 
assignment of custody (Section II, point i) and the substance of the custody (Section II, point ii). As already mentioned, data about the time each parent is allowed to spend with the child are unfortunately not available. ${ }^{10}$ Therefore, we focus on outcomes that reflect financial arrangements, which can also be informative with respect to visitation periods as the reform prescribes that custodial length mirrors child support arrangements. The expected outcomes are the following:

A1. Custody Assignment, measured as the probability that the mother gets sole legal custody over the child.

A2. Family House, measured as the probability that the woman gets the right to keep the family house.

A3. Indirect Child Support, measured as the probability that the father is obliged to provide money (indirect support) for child maintenance to the mother.

A4. Money for Indirect Child Support, measured as the amount of money that the father is obliged to provide (indirect support) to the mother.

As explained in Section II, we expect a negative impact of the reform on these outcomes.

B) Non expected outcomes. The law does not prescribe a change with respect to the past for these outcomes. Nonetheless, as they matter for post-separation overall arrangements, they have to be monitored to ensure that they are not modifying (reinforcing or attenuating) the expected impact of the reform on the outcomes for which a change is prescribed. We focus on two outcomes that reflect financial arrangements.

B1. Alimony, measured as the probability that the husband is obliged to provide a sum of money for the maintenance of the wife.

B2. Money for Alimony, measured as the amount of money that the husband is obliged to provide for the maintenance of the wife.

C) Indirect outcomes. These are the outcomes that capture the impact of the introduction of the Law 54/2006 on parent's incentives to separate, procrastinate the legal dispute, and on the efficiency of the judiciary.

C1. Separations with no Agreement, measured as the share of separations with no mutual consent. As in other countries, separating couples might find an agreement on all the aspects related to the postseparation regime (both physical custody and financial arrangements) and submit the agreement to the court. This is the case of mutual consent (separazioni consensuali). If an agreement is not found the

\footnotetext{
10 The administrative data on separations and divorce only provide information on the time the non custodial parent spends with the child(ren) in the case of sole custody. No information is collected for the cases in which legal joint custody is assigned.
} 
separating mates submit their respective proposals and the judge takes a decision. These are named separations with no agreement (separazioni giudiziali).

C2. Judicial Efficiency, measured as the number of days needed for a judge to conclude a trial.

C3. Applicant's Gender, measured as the fraction of women filling the application for a separation. The expectations of each separating partner on post-dissolution rights and responsibilities is going to have an impact on the odds of requesting a separation.

In the empirical analysis we focus on separating couples because the relevant decisions on family issues are usually taken at separation decree and usually they are confirmed with minor changes at divorce decree. Anecdotic evidence suggest that In Italy a relevant share of separated couples never request the divorce decision (their splitting process ends with the separation decree). Moreover, the divorce decision takes usually very long after the separation, when custody issues are not longer relevant (as the minors become adults). Our sample (that excludes observations with missing values on explanatory variables consists of 495,333 treated couples (separating couples with dependent children at time of separation) and 374,302 couples in the control group (childless couples or with no children under 18 years). Table 1 reports summary statistics for the outcomes, by timing of the reform and treatment status. From the table a causal empiricist would guess that the reform resulted in a poor implementation, except for the share of sole legal custody assignments. Clearly, this impression has to be validated by a more rigorous empirical analysis, which we perform in the next sections. Appendix I presents the descriptive statistics for the variables that we use as controls. Note that along a high number of dimensions (for instance, education, labor market status) treated and controls seem to be quite comparable. All the monetary variables have been deflated by the Consumer Price Index (base 2010).

\section{[Table 1]}

\section{Identification Strategy}

To estimate the causal effect of the introduction of the Law 54/2006 on the outcomes listed in Sect. III, we use a difference-in-differences approach (see, for instance, Angrist and Pischke, 2009) that compares the changes in the outcomes for splitting couples with minors (for whom the new rules apply after March 2006) with 
changes in the outcomes for splitting couples with no minors (for whom the new rules do not apply). ${ }^{11}$ Operationally, we estimate the following regression model:

$$
Y_{i j t}=\alpha_{0}+\alpha_{1} \text { POST }_{t}+\alpha_{2} \operatorname{TREAT}_{i}+\alpha_{3}\left(\mathrm{POST}_{t}^{*} \mathrm{TREAT} T_{i}\right)+\alpha_{4} X_{i t}+\eta_{t}+\gamma_{j}+\varepsilon_{i j t}
$$

where $Y_{i j t}$ is the outcome of interest (for instance, family house assigned to the mother), for couple $i$ decided by court $j$ in period $t$; the dummy POST t takes the value one from March 2006 onwards and zero otherwise; the dummy TREATi is equal to one for treated couples (those with at least one dependent minor) and zero otherwise; $X_{i t}$ is a vector of additional covariates (which includes controls for individual demographic characteristics, history of the marriage, labor market status and marriage characteristics); $\eta_{t}$ is a set of time dummies, $\gamma_{j}$ a set of court dummies and $\varepsilon_{i j t}$ is the error term. ${ }^{12}$

The coefficient $\alpha_{1}$ captures the effect on $Y_{i j t}$ of the simple passing of time, from the period before the reform to that after it, for both group of treated and controls. The coefficient $\alpha_{2}$ captures the effect on $Y_{i j t}$ of having children irrespective of the time period, i.e. it represents permanent differences between the treated and the controls. The interaction coefficient $\alpha_{3}$ is the effect of interest because it captures the differential impact of the 2006 reform on splitting couples with children compared to splitting couples without dependent children. We also control for time fixed effects $\left(\eta_{t}\right)$ and court fixed effects $\left(\gamma_{j}\right)$. The latter in order to take into account possible territorial heterogeneity in the application of the Law 56/2006, which might derive, for instance, because judicial inefficiency has a strong local component (see: Carmignani and Giacomelli, 2009).

Note that for some of the outcomes, i.e custody assignment, indirect child support and money for indirect child support, there is no sensible control group, as the outcomes are observed only for couples with children. For these outcomes we simply estimate a pre-post effect for the treated group. In other words, we display the estimates we obtain for the dummy $P O S T_{t}$ in equation (1) for a sample that includes only treated. ${ }^{13}$ Admittedly, the results obtained with the pre-post estimations can be considered less reliable than those referring to the difference-in-differences (DiD), as they might confound time trends as part of the treatment. ${ }^{14}$

\footnotetext{
11 A similar strategy is used by Böheim et al, (2012). They also make use of a second control group, which is deemed more desirable. This control group is restricted only to households with the youngest child 18 years or older (therefore, it rules out childless families). We have also replicated all our estimates by using this additional control group (which shrinks our control sample greatly) with results (available upon request) that are always very similar to those documented in Sect. VI.

12 We present the results we obtain from collapsing the time series information into a single pre- and post- intervention period. As shown by Bertrand et al. (2004), this takes care of the potential inconsistency of the standard errors due to serial correlation.

${ }^{13}$ Note however that the use of a large number of controls (see: Sect. V) helps us to ensure that the separating couples with minors would have been comparable over time in the absence of the treatment.

14 As we checked, however, no clear time trend in the three outcomes exists for the pre-reform period.
} 
Nevertheless, were they consistent with what is obtained for the other outcomes with the DiD strategy, we would obtain a more complete picture of the effects of the joint custody law.

All in all, had the Law 54/2006 been implemented in courts, one would expect negative signs for the coefficient $\alpha_{3}$ ( $\alpha_{1}$ for pre-post estimates) when we regress the type A (expected) outcomes and a zero coefficient for the type B (non expected) outcomes. As for the type C (indirect) outcomes, based on previous research (see: Halla and Höltz, 2007; and Böheim et al, 2012) one would guess a negative impact on the share of separation with no mutual consent, a boost on judicial efficiency, and a decrease of the fraction of women filling the application for a separation (that is: negative signs for the coefficient $\alpha_{3}$ for all these outcomes).

\section{Results}

Sect. V.1 presents the evidence on the impact of the Law 54/2006 on our set of expected and non expected outcomes. Then, we focus (Sect. V.2) on the impact on the indirect outcomes. Finally, Sect. V.3 provides some robustness with respect to potential time-varying omitted variables at the court level.

\section{V.1 The impact of the Law 54/2006 on expected and non expected outcomes.}

We start by analyzing the impact of the Law 54/2006 on the legal assignment of custody. As explained in Sect. II, the reform was quite unambiguous in this respect: after March 2006 the judge is requested to assign joint legal custody, unless some very specific circumstances, to be documented with a judgment written statement (provvedimento), make sole custody preferable. Figure 1 documents the fractions of legal custody assignments (over the total judgments for separations with minors) to mother, father and both parents over the 2000-2010 period. Starting from March 2006, the share of sole legal custody to mother decreases monotonically, while the share of joint custody assignment increases specularly. The share of sole custody to father is instead almost negligible over the whole period.

[Figure 1]

Table 2 provides the (pre-post) estimates of the likelihood for a mother of receiving sole legal custody over the first child 15 for our sample of 447,973 treated couples with minors that separated over the 2000-2010 period. Column 1 displays the results of the impact of the Law 56/2006 when only time and court fixed effects are

\footnotetext{
15 In case of more than a child, the custody assignment is over the same for all children in the overwhelming majority of the cases. For robustness, we also used as outcome the likelihood for a mother of receiving sole legal custody over the youngest child, with results very similar to those presented in Table 2 .
} 
included as controls. The point estimate for the coefficient $P O S T_{t}$ in equation (1) suggests that in the aftermath of the reform there was a substantial drop (slightly below 25 percentage points, and highly significant) of the likelihood that a judge goes for sole maternal custody.

This estimate is quite stable across the specifications from Column 2 to Column 5 , in which we increasingly include additional covariates. ${ }^{16}$ Column 2 includes (both for husband and wife) the civil status before the marriage (which could be: single, divorced, widowed), the age, the nationality and a dummy for foreign born individuals (irrespective of the nationality), the level of education (low education, high school diploma and university achievement). Column 3 adds the duration of the marriage and the number of children present in the household. Column 4 includes (both for husband and wife) a number of labor market covariates: labor market status (employed, unemployed, out of the labor force), occupation (entrepreneur, self-employed, white-collar, blue-collar) and sector of activity (agriculture, manufacturing, services, public sector, other). Note that the labor market covariates proxy for the (unobserved) income and wealth status of the separating mates. Finally, Column 5 adds controls for whether the wedding was religious and the types of matrimony financial agreement (joint or disjoint management of the family wealth). These inclusions seem to be warranted. Religious weddings might capture some deep feelings related to the pursuance of a matrimonial relation, irrespective of the circumstances. Matrimony financial arrangement might also pick up additional incentives to stay in or move out from a relationship. For instance, in the case of joint management, the wealth loss (gain) for the wealthier (poorer) mate is amplified. All in all, we find that the probability that the mother gets sole legal custody over the child(ren) drastically decreases. For this outcome, the change prescribed by the Law 54/2006 has actually been implemented in courts. ${ }^{17}$

\section{[Table 2]}

Table 3 reports the difference-in-differences estimates for the probability that the woman gets the right to keep the family house. As explained in Sect. III, the impact of the reform on this outcome should be negative. Quite surprisingly, this does not seem to be the case. The likelihood for a mother to keep the house after the reform (POST*TREAT coefficient) increases by about 1 percentage point and it is stable across all the specifications. ${ }^{18}$

\footnotetext{
16 To save space, we do not report the estimates for the covariates. They are available upon request.

17 As robustness, we have replicated all the results presented in Sect. VI by using as a restrict sample of marriages formed before the reform. As Halla (2013), we are concerned that to the extent that the Law 54/2006 modifies the incentives to separate, it might affect also the selection process into the marriage. The results we obtain by using this restricted sample (available upon request) do not differ from those presented in the text. As we will see, this is an expected outcome: the degree to which judiciary outcomes results modified with respect to the pre-reform period is very little.

18 On average over the period 2000-2010, the presence of kids increases substantially the probability for a mother to keep the most valuable family asset, compared to separating couples with no children. The estimates for the coefficient TREAT in Table 3 suggest
} 
Tables 4 and 5 provide the (pre-post) results for the outcomes related to child support. As mentioned in Section III, the Law 54/2006 envisages a move from indirect support to direct support. This means that both parents are financially obligated to support the child, each for some types of goods and services. Therefore, one would expect that both the fraction of husbands obliged to provide a sum of money to the wife and the amount of money provided decrease substantially. Again, this does not seem to be the case. The probability that the father is obliged to provide a sum of money to the mother for child maintenance (Table 4) decreases after the reform but only very modestly. The estimated effect is slightly below 3 percentage points, while the fraction of husbands obliged to provide indirect support in the years before the reform was equal to $87 \%$ (see Table 1). Even more surprisingly, the amount of money that the father is obliged to provide to the mother (Table 5) remains unchanged with respect to the pre-reform situation.

\section{[Table 4]}

\section{[Table 5]}

Tables 6 and 7 provide the difference-in-differences results for our non-expected outcomes. They refer to alimonies, which are not involved in the reform (see: Sect. II). Nevertheless, it is important to analyze whether they changed because of the introduction of the joint custody. As also underscored by Mnookin and Kornhauser (1979), alimony and child support are fungible: both involve periodic money payments and, indeed, are often paid by a single check from the non-custodial parent. Therefore, to the extent that alimony changes as effect of the reform, the impact should be accounted as part of the overall post-separation financial consequences of having changed the rule for custody. ${ }^{19}$ As for the results, we find that the probability that husband is obliged to provide a money support to the wife (Table 6) increases by over 2 percentage points. This is a considerable jump: it is half of the overtime average for men with minors (with respect to those without; see the estimates for the coefficient TREAT); while the fraction oh husbands obliged to provide alimonies in the years before the reform was equal to $25 \%$ (see Table 1). As effect of the reform, the amount related to the maintenance of the woman decreases of about 20 euros (6\% of the average amount for alimony for separating couples with minors before the introduction of the Law 54/2006: Table 1).

\footnotetext{
that the effect is over $20 \%$ irrespective of whether the income status of the two spouses is controlled for in the regressions (see, for instance, the comparison between column 3 and column 4).

${ }^{19} \mathrm{~A}$ change in alimony might reveal something on the judge preferences over the degree to which the provisions of the law have to be translated in actual court decisions. For instance, judges who are not happy with indirect support, but feel that they have nevertheless to obey to the law principles, might act using alimony to counterbalance the negative impact of indirect support on the money received by the custodial parent.
} 
[Table 6]

[Table 7]

The evidence provided so far refer to all separations, both those with a prior mutual consent (consensuali) and those with no previous agreement (giudiziali). It is import to check the extent to which the outcomes from these two types of separations differ. Table 8 displays for each outcome the relevant sample-split results. We find robust evidence that where there is no mutual consent the judge takes a decision that is more favorable to the mother, respect to those where a pre-court agreement is reached. Compared to the outcomes of the separations by mutual consent, the decrease in the likelihood for a mother of obtaining sole legal custody is estimated to be less than a half (Columns 1 and 2); the probability for the woman of keeping the family house increases of about 5 times (Columns 3 and 4); the reduction in the likelihood for a father to be obliged to provide a sum of money for child support is less pronounced (Columns 5 and 6); the amount of money involved is substantially higher (over $33 €$ compared to zero: Columns 7 and 8); finally, the difference for the likelihood to be obliged to pay alimony (Columns 9 and 10) is about one fourth, while the amount involved does not receive the reduction that applies for mutual consent dissolutions (Columns 11 and 12). This evidence strongly suggests that failing to find an agreement imposes substantial extra-costs on the father's side.

[Table 8]

The results documented so far can be easily summarized. First, the legal assignment of joint custody found application in courts. Second, the provisions of the law regarding the substantive aspects of the joint custody for which the law left some discretion on the judge side - did not found actual implementation. Third, the outcomes from separations with no agreement tell a consistent story: compared with those from mutual consent they are always less favorable to husbands.

A few aspects of our results deserve a comment.

First, we have been able to document what has happened with the post dissolution financial arrangements. Our data are however silent on a key judge determination: the amount of time that each parent is allowed to spend with the child(ren). Note however that to the extent that the financial arrangements also reflects "the actual time spent with the child and the extent of domestic care provided by each parent", as required by the law (see Sect. II), it is reasonable to argue that the court decisions did not innovate with respect to the past 
also with regard to the time that each parent is allowed to spend with the child(ren). This is also supported by plenty of anecdotic evidence. ${ }^{20}$

Second, our reading of the evidence points to a substantial opposition of the judiciary to implement the new principles endorsed by the Law 54/2006. This opposition materializes with reference to the substantive aspects of the reform, where plenty of implementation power has been left to the judges, while the formal aspect of the law, the legal assignment of custody, was strictly applied, as no discretion has been envisaged in that case. A potential counterargument to our reading is that we might be erroneously attributing to judges what is instead a voluntary outcome of the bargaining between splitting partners approaching the separation. We believe that this counterargument can be easily dismissed. Plenty of anecdotic evidence suggests that the fathers are not happy with the current decisions of the Italian courts (see: Zavattiero, 2012). Moreover, if the observed outcomes reflected the preferences of the separating parties over custody and financial arrangements we should have found that, compared with the separations with mutual consent, the outcomes referring to giudiziali - in which the leeway of the judges is magnified - were more in line with the principle of the law, while the opposite receives empirical support. Finally, the possibility that the observed outcomes reflect the preferences of the separating mates involved is not confirmed by theoretical reasoning. ${ }^{21,22}$

\section{V.2 The impact of the Law 54/2006 on indirect outcomes.}

Table 9 documents that as effect of the introduction of the joint custody law there was a substantial increase in the fraction of disputes with no pre-court agreement (giudiziali). The estimated increase in litigiousness after the reform is above 1 percentage point (coefficient $P O S T^{\star} T R E A T$ ), where the overtime differential average for couples with minors respect to those without kids (coefficient TREAT) is around 2 percentage points. This result is likely to be linked to the little degree to which the principles introduced by the reform have been translated into actual court decisions, rather than to the principles per se. Note that recent theoretical work by Halla and Höltz (2007) shows that the introduction of joint custody enables parents to find an agreement otherwise not feasible in the sole custody regime. The empirical evidence provided by the same authors, and referring to the case of Austria, shows that the move to joint custody causes an increase in the fraction of

\footnotetext{
20 See, for instance: http://www.avvenire.it/Cronaca/Pagine/affido-condiviso-purtroppo-teoria.aspx.

21 The Coase theorem (Coase, 1960) applied to marriage dissolution suggests that legal rules do not affect outcomes when the parties can bargaining around the rules. As explained by Gonzàlez-Val and Marcén (2012), the move from sole custody to a regime in which the father is allowed to spend more time with the child(ren) is associated (in Coesian terms) with a reduced willingness of the father to financially compensate the mother. Since we observe that for the mothers financial benefits are not reduced, the idea that the impact of the Law 54/2006 reflects the voluntary bargaining between mates does not receive empirical support.

22 In a sense, our estimates might even provide a lower bound of the degree to which the judges failed to apply the principles of the law. Note that the lawyer fees increase substantially by moving from mutual consent to separations with no agreement. Therefore, given that the outcomes of the separations with no agreement is even less favorable to fathers (and if the results of our paper were known to them!), some of them might decide to agree on unfavorable terms (and saving the fees) in the pre-court agreements.
} 
separations by mutual consent. Therefore, the increase in giudiziali we observe is probably not to relate to the principles of the law, which are very similar in Italy and Austria, but to the courts' implementation. ${ }^{23}$

\section{[Table 9]}

Table 10 shows the effect of the introduction of the reform on judicial inefficiency, measured as the number of days a judge takes to conclude a trial. The impact is a substantial boost. Our estimates suggest that separating couples with minors take 16 extra days to conclude their separating trial after the reform as compared to childless couples or couples with children older than 18. This effect is in line with what is documented above with respect to the degree of litigiousness.

[Table 10]

Finally, we present in Table 11 the impact of the reform on the gender composition of the applicants for separations. This outcome is an important 'reduced form' illustration of how the reform changed the incentives to family dissolution for each spouse. For instance, to the extent that the reform increases the probability for a mother to keep the family house and other financial benefits, one would expect a positive impact of the Law $54 / 2006$ on the fraction of women requesting a separation, since the incentives for the women to separating are amplified. As matter of fact, our results document that after the introduction of the law there has been an increase in the fraction of women requesting a separation by about 1.5 percentage points. Note also that the fraction of women requesting a separation (as measured by the period average) in case of couple with minors is $5.6 \%$ higher than that referring to couple without minors.

\section{[Table 11]}

\section{V.3. Could the failure in implementation reflect judicial inefficiency?}

On the whole, our results highlight that the reform was only cosmetically applied by the judges. This could be related to judicial inefficiency. As mentioned by the World Bank (2012) the Italian judiciary is featured by high inadequacy. For instance, the average duration of trials is 1,210 days, three times as much as the average duration in Europe. Carmignani and Giacomelli (2009) show that Italy's judicial inefficiency has a strong local component (for instance, in the most efficient court, Torino, the days needed to conclude a trail are $1 / 3^{\text {rd }}$ of those required in the most inefficient one, Messina). Having introduced court fixed-effects, however, we can

\footnotetext{
${ }^{23}$ As we checked, there is no evidence of gender difference in the likelihood to apply for a giudiziale. In light of the remark of the previous footnote on a potential downward bias for our results, this fact might imply that either the judges' stance, more detrimental to the fathers, is not anticipated by the parties or that it is instead fully anticipated.
} 
rule out that our results are driven by time-invariant differences in the efficiency of the local courts. However, this might not be enough as time-variant differences in efficiency might materialize because of the introduction of the Law 54/2006. While the introduction of a new regulation always requires judges to catch up with the novelty, the Law 54/2006 is quite peculiar because it requires judges to use much more discretion than under the previous regime of sole custody. Therefore, it is plausible that the relatively more efficient courts have been more able to make use of discretion in the spirit of the new principle introduced, while the relatively less efficient courts have been unable to cope with the extra discretion they have been endowed with and have tended to replicate the old regime. If this is the case, then the results can be attributed to time varying courts' ineptitude. To check for this possibility, we replicate in Table 12 all the results obtained by including a set of court*time fixed effects. This allows us to differentiate away the court-specific time trend. To the extent that a change in local inefficiency is what drives our findings, we should obtain estimates quite different for those obtained previously. Our results show that this does not seem to be the case: for all outcomes our estimates closely resemble those obtained before. 24

\section{[Table 12]}

\section{Conclusions}

Our results have showed that the law on joint custody did not find an actual application in courts. Apart from the assignment of joint legal custody, for which the judges had basically no discretion, the remaining financial provisions of the law remained unapplied. Very likely, the provisions of the law referring to visitation remained unapplied too. We have also showed that Italy's judiciary inefficiency is unlikely to account for the observed pattern of outcomes.

One possible interpretation for the findings refer to the fact that in the Italian case family justice is a femaledominated business. This might explain why judgment is performed in a gender-biased way, basically favoring the mothers at the expenses of the fathers, insofar female judges give more weight to deep feelings regarding gender issues. As documented by Halla and Höltz (2007), in the case of Austria female judges are biased against joint custody. Narrative evidence referring to the case of Italy points to the same direction. According to Maglietta (2006), the ostracism to joint custody has to be related to feminism views that consider sole custody as the compensation for the historical discrimination against women. Unfortunately, our dataset does not include the gender of the judge. Therefore the appropriateness of this interpretation cannot be further investigated. Note, however, that for this interpretation being appropriate it is not required that gender-biased

\footnotetext{
${ }^{24}$ This robustness check takes care of all potential omitted variables varying over time at the court level. For instance, it controls for
} judiciary discretion varying accordingly to the local labor market stance, as suggested by Ichino et al (2002). 
practices are applied on purpose across the entire judiciary. As underscored by Gennaioli and Shleifer (2008), the judge aversion to reversal on appeal might spur a replication of the previous decisions. Therefore, an initial critical mass of gender-biased decision might have propagated around the courts.

The fact that court implementation has washed out the new principles introduced with the Law 54/2006 might imply huge private and social costs that deserve to be mentioned. First, and most notably, for the Italian children involved in the dissolution of their family the desirable consequences of the joint custody, mentioned in Sect. I, are not going to materialize. Since for these children the right to have a balancing relation with both parents is precluded, severe emotional and psychological costs might be on their way. Second, for both the separating mates the legal costs have very likely increased. Both the increase in the share of separations with no agreement and the number of days a judge takes to conclude a trial point to this direction. Beyond the money spent for the lawyers' fees, there has likely been a surge in expenditures for the bills of consultants (mainly, psychologist and psychiatrists), who are appointed by the judge, to advice on the best solution in the interest of the children (left by the law to the judge discretion), and paid by the parents. Anecdotic evidence (see: de Blasio and Dini, 2009) suggests that a whole consulting industry, with precarious scientific foundations and low deontological status, has recently emerged. Third, a law approved by the Parliament to favor the children has been turned down by the judicial body. The disruption of the democratic procedure according to which the Parliament makes the laws and the Judiciary applies it to the facts of each case - might not be without consequences.

Finally, our results highlight that in the case of Italy enabling judges with more discretion was not a good idea. The obvious policy recommendation that stems from this is a restatement of the law that reduces the elements of judgment. If subsequent research shows that the gender of the judge is key for the observed judiciary outcomes, then a good policy remedial should be that of ensuring a more balanced presence of judges of both genders when the prospects of the children are at play. This could provide more balanced decisions, without scarifying discretion. Since it seems that the Italian Parliament is going to discuss soon about possible amendments to the Law $54 / 2006,25$ we hope that the results documented in this paper might be useful to bring the 2006 reform back on the track of the principles originally envisaged.

25 See: http://www.senato.it/leg/16/BGT/Schede_v3/Ddliter/32138.htm. 


\section{References}

Allen B., Nunley J.M., and Seals, A. (2011) "The Effect of Joint-Child-Custody Legislation on the Child-Support Receipt of Single Mothers," Journal of Family and Economic Issues, 32, 1, 124-139.

Angrist J.D.and Pischke J. (2009) Mostly Harmless Econometrics: An Empiricist's Companion, Princeton University Press.

Bank of Italy (2011) La ricchezza delle famiglie italiane 2010. Supplementi al Bollettino statistico.

Bank of Italy (2012) I bilanci delle famiglie italiane nel 2010. Supplementi al Bollettino statistico.

Barlett K.T.and Stack C.B. (1986) "Joint Custody, Feminism and the Dependency Dilemma," Berkeley Women's Law Journal, 2, 9-41.

Bauserman R. (2002) "Child Adjustment in Joint-Custody Versus Sole-Custody Arrangements: A Meta-Analytic Review," Journal of Family Psychology, 16, 1.

Bianco, M., Giacomelli S., Giorgiantonio C.,. Palumbo G, Szego B. (2007) "La durata (eccessiva) dei procedimenti civili in Italia: offerta, domanda o rito?," Rivista di Politica Economica, 97, III, IX-X.

Böheim R., Francesconi M., and Halla M. (2012) "Does custody law affect family behavior in and out of marriage?," IZA DP 7064.

Brinig, M. F. and Buckley F.H. (1998), "Joint Custody: Bonding and Monitoring Theories,", Indiana Law Journal, 73,2, 393-452.

Carmignani A. and Giacomelli S. (2009) "La giustizia civile in Italia: i divari territoriali", Banca d'Italia, Questioni di economia e finanza, n. 40.

Coase R.H. (1960) "The Problem of Social Cost," Journal of Law and Economics, 3, 1-44

de Blasio G. and Dini M. (2009) L'affido condiviso in Italia. NelMerito.com (7 maggio 2009)

Donohue J. and Siegelman P. (1991) "The Changing Nature of Employment Discrimination Litigation," Stanford Law Review, 43: 983-1033.

Gaglione M.P. and Malfettani L. (2008) L'affido condiviso. Esselibri-Simone.

Gennaioli N. and Shleifer A. (2008) “Judicial Fact Discretion," Journal of Legal Studies, 37, 1, 1-35,

González-Val R., and Marcén M. (2012). "Unilateral divorce versus child custody and child support in the U.S.," Journal of Economic Behavior \& Organization, 81, 2, 613-643.

Halla M. (2013) "The Effect of Joint Custody on Family Outcomes," Journal of the European Economic Association, 11,2, 278-315.

Halla M. and Höltz C. (2007) "Bargaining at Divorce: The Allocation of Custody," IZA DP 7064. 
Ichino A., Polo M., and Rettore E. (2003) "Are judges biased by labor market conditions?," European Economic Review, 47, 5, 913-944

Macoby E.E. and Mnookin R.H. (1997) Dividing the Child: Social and Legal Dilemmas of Custody. Harvard University Press.

Maidment S. (1984) Child Custody and Divorce: The Law in Social Context. Croom Helm.

Maglietta M. (2006) L'affidamento condiviso dei figli. Franco Angeli.

Mason M.A. (1994) From Father's Property to Children's Rights: The History of Child Custody in the United States. Columbia University Press.

Mnookin R.H. and Kornhauser L. (1979) "Bargaining in the Shadow of the Law: The Case of Divorce." Yale Law Journal, 88,5, 950-997.

Nunley J.M. and Seals A. (2011) "Child-Custody Reform, Marital Investment in Children, and the Labor Supply of Married Mothers", Labour Economics, 18, 1, 14-24.

Teng Wah L. (2009) "From Maternal Preference to Joint Custody: The Impact of Changes in Custody Law on Child Educational Attainment". Mimeo, St. Francis Xavier University.

Weiss Y. and R.J. Willis, (1985) "Children as Collective Goods and Divorce Settlements", Journal of Labor Economics 3, 3, 268-292

World Bank (2012) World Bank (2012) Doing Business. Smarter Regulations for Small and Medium Sized Enterprises, Washington D.C.

Zavattiero C. (2012) Poveri padri. Ponte alle Grazie. 
Fig. 1 Sole legal custody to the mother (over total separations with minors)

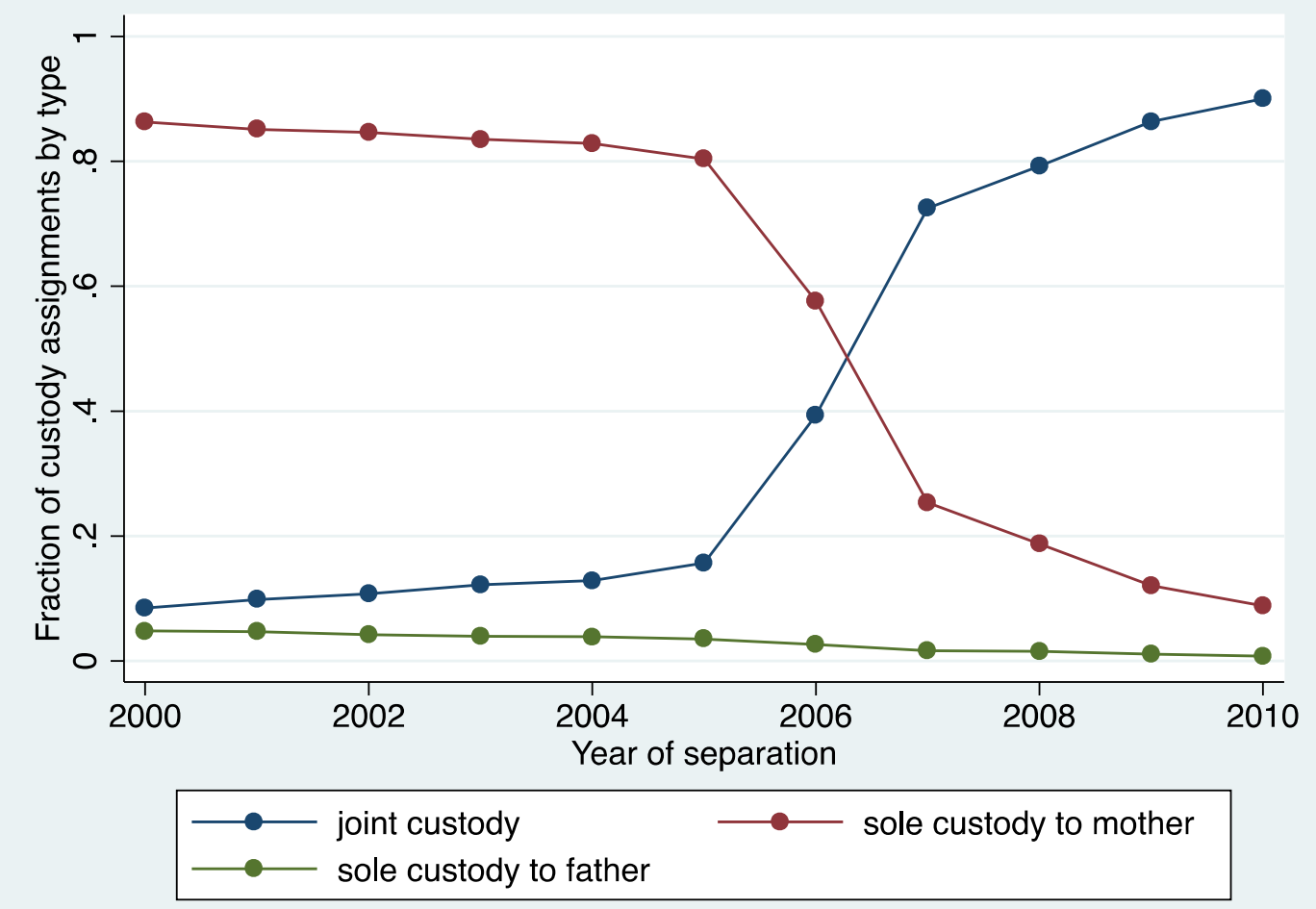

Source: Istat - Dataset on separations and divorces, 2000-2010. Before March 2006 the figure considers as joint custody the alternate custody that was envisaged under the pre-reform regulation. 
Table 1. Descriptive statistics for the outcomes

\begin{tabular}{|c|c|c|c|c|}
\hline & $\begin{array}{c}\text { (1) } \\
\text { Before } \\
\end{array}$ & $\begin{array}{c}(2) \\
\text { After } \\
\end{array}$ & $\begin{array}{c}\text { (3) } \\
\text { Before }\end{array}$ & $\begin{array}{c}\text { (4) } \\
\text { After } \\
\end{array}$ \\
\hline Sole custody to mother & 0,83 & 0,22 & - & - \\
\hline Family house to mother & 0,70 & 0,69 & 0,43 & 0,41 \\
\hline Indirect child support & 0,87 & 0,85 & - & - \\
\hline Money for indirect child support & $404,56(438,37)$ & $481,93(441,95)$ & - & - \\
\hline Alimony & 0,25 & 0,25 & 0,20 & 0,19 \\
\hline Money for alimony & $351,58(613,97)$ & $419,64(641,72)$ & $474,74(854,60)$ & $563,81(930,41)$ \\
\hline Separation with No Agreement & 0,14 & 0,15 & 0,12 & 0,12 \\
\hline Judicial Inefficiency & $239,09(344,02)$ & $260,74(369,80)$ & $209,33(307,15)$ & $223,49(318,93)$ \\
\hline Gender of the Applicant & 0,21 & 0,23 & 0,15 & 0,12 \\
\hline
\end{tabular}

Source: Istat - Dataset on separations and divorces, 2000-2010. Each entry denotes the sample mean (for continuous variable the standard deviation is reported in parenthesis). 
Table 2. The Impact of Joint Custody on Sole Legal Custody to the Mother (Outcome: A1)

\begin{tabular}{cccccc}
\hline & $(1)$ & $(2)$ & $(3)$ & $(4)$ & $(5)$ \\
\hline POST $(\alpha 1)$ & & & & $-0.238^{* *}$ & $-0.238^{* *}$ \\
& $-0.239^{* *}$ & $-0.238^{* *}$ & $-0.238^{* *}$ & $(0.012)$ & $(0.012)$ \\
Individual & $(0.013)$ & $(0.012)$ & $(0.012)$ & YES & YES \\
History of the marriage & NO & YES & YES & YES & YES \\
Labor market & NO & NO & YES & YES & YES \\
Type of marriage & NO & NO & NO & NO & YES \\
Observations & NO & NO & & 447,973 & 447,973 \\
R-squared & 447,973 & 447,973 & 447,973 & 0.442 & 0.442 \\
& 0.436 & 0.440 & 0.440 & & \\
\hline
\end{tabular}

Notes. The outcome is the likelihood for a mother of receiving sole legal custody over the first child. Time and Court fixed effects are included in all specifications. Standard errors are corrected to allow for clustering at the court level. ${ }^{* *}\left({ }^{*}\right)[+]$ denotes significance at the $1 \%(5 \%)[10 \%]$ level. Individual controls include (both for husbands and wives): civil status before the marriage (single, divorced, widowed), age, a dummy for foreign born, nationality, education (dummies for high school and university achievements). History of the marriage controls include: duration of the marriage and number of children. Labor market controls include (both for husbands and wives): labor market status (employed, unemployed, out of the labor force), work status (entrepreneur, self-employed, white-collar, blue-collar), sector of activity (agriculture, services, manufacturing, public sector). Type of marriage controls include: religious weddings and prenuptial agreement on asset division (community vs separate property).

Table 3. The Impact of Joint Custody on Family House to the Mother (Outcome: A2)

\begin{tabular}{|c|c|c|c|c|c|}
\hline & (1) & $(2)$ & (3) & (4) & (5) \\
\hline POST ( $\alpha 1)$ & $\begin{array}{l}-0.011^{*} \\
(0.005)\end{array}$ & $\begin{array}{l}-0.013^{*} \\
(0.005)\end{array}$ & $\begin{array}{l}-0.012^{*} \\
(0.005)\end{array}$ & $\begin{array}{l}-0.012^{*} \\
(0.005)\end{array}$ & $\begin{array}{l}-0.012^{*} \\
(0.005)\end{array}$ \\
\hline TREAT $(\alpha 2)$ & $\begin{array}{l}0.261^{* *} \\
(0.006)\end{array}$ & $\begin{array}{l}0.273^{* *} \\
(0.006)\end{array}$ & $\begin{array}{l}0.208^{* *} \\
(0.006)\end{array}$ & $\begin{array}{l}0.206^{\star *} \\
(0.005)\end{array}$ & $\begin{array}{l}0.206^{* *} \\
(0.005)\end{array}$ \\
\hline $\mathrm{POST}^{*} \mathrm{TREAT}(\alpha 3)$ & $\begin{array}{l}0.011^{* *} \\
(0.004)\end{array}$ & $\begin{array}{l}0.012^{* *} \\
(0.004)\end{array}$ & $\begin{array}{l}0.011^{* *} \\
(0.004)\end{array}$ & $\begin{array}{l}0.010^{*} \\
(0.004)\end{array}$ & $\begin{array}{l}0.010^{*} \\
(0.004)\end{array}$ \\
\hline Individual & NO & YES & YES & YES & YES \\
\hline History of the marriage & NO & NO & YES & YES & YES \\
\hline Labor market & NO & NO & NO & YES & YES \\
\hline Type of marriage & NO & NO & NO & NO & YES \\
\hline $\begin{array}{l}\text { Observations } \\
\text { R-squared }\end{array}$ & $\begin{array}{c}869,636 \\
0.083\end{array}$ & $\begin{array}{c}869,636 \\
0.104\end{array}$ & $\begin{array}{c}869,636 \\
0.106\end{array}$ & $\begin{array}{c}869,636 \\
0.109\end{array}$ & $\begin{array}{c}869,636 \\
0.110\end{array}$ \\
\hline
\end{tabular}

Notes. The outcome is the probability that the woman gets the right to keep the family house. Time and Court fixed effects are included in all specifications. Standard errors are corrected to allow the clustering of the residuals at the court level. ${ }^{* *}\left({ }^{*}\right)[+]$ denotes significance at the $1 \%(5 \%)[10 \%]$ level. Individual controls include (both for males and females): civil status before the marriage (single, divorced, widowed), age, a dummy for foreign born individuals, nationality, education (dummies for high school and university achievements). History of the marriage controls include: duration of the marriage and number of children. Labor market controls include (both for males and females): labor market status (employed, unemployed, out of the labor force), work status (entrepreneur, self-employed, white-collar, blue-collar), sector of activity (agriculture, services, manufacturing, public sector). Type of marriage controls include: religious weddings and marriage financial agreement (joint or disjoint management of the family wealth). 
Table 4. The Impact of Joint Custody on Indirect Child Support (Outcome: A3)

\begin{tabular}{|c|c|c|c|c|c|}
\hline & (1) & $(2)$ & (3) & (4) & (5) \\
\hline POST ( $\alpha 1)$ & $\begin{array}{c}-0.035^{\star *} \\
(0.005)\end{array}$ & $\begin{array}{c}-0.037^{\star *} \\
(0.005)\end{array}$ & $\begin{array}{c}-0.028^{* *} \\
(0.004)\end{array}$ & $\begin{array}{c}-0.028^{* *} \\
(0.004)\end{array}$ & $\begin{array}{c}-0.028^{\star *} \\
(0.004)\end{array}$ \\
\hline Individual & NO & YES & YES & YES & YES \\
\hline History of the marriage & NO & NO & YES & YES & YES \\
\hline Labor market & NO & NO & NO & YES & YES \\
\hline Type of marriage & NO & NO & NO & NO & YES \\
\hline Observations & 869,636 & 869,636 & 869,636 & 869,636 & 869,636 \\
\hline R-squared & 0.018 & 0.046 & 0.510 & 0.513 & 0.513 \\
\hline
\end{tabular}

Notes. The outcome is the probability that the father is obliged to provide a sum of money to the mother for child maintenance (indirect support). Time and Court fixed effects are included in all specifications. Standard errors are corrected to allow the clustering of the residuals at the court level. ** $\left.{ }^{*}\right)[+]$ denotes significance at the $1 \%(5 \%)$ [10\%] level. Individual controls include (both for males and females): civil status before the marriage (single, divorced, widowed), age, a dummy for foreign born individuals, nationality, education (dummies for high school and university achievements). History of the marriage controls include: duration of the marriage and number of children. Labor market controls include (both for males and females): labor market status (employed, unemployed, out of the labor force), work status (entrepreneur, self-employed, white-collar, blue-collar), sector of activity (agriculture, services, manufacturing, public sector). Type of marriage controls include: religious weddings and marriage financial agreement (joint or disjoint management of the family wealth).

Table 5. The Impact of Joint Custody on Money for Indirect Child Support (Outcome: A4)

\begin{tabular}{cccccc}
\hline & $(1)$ & $(2)$ & $(3)$ & $(4)$ & $(5)$ \\
\hline POST $(\alpha 1)$ & 3.049 & 1.338 & 1.125 & 0.873 & 1.387 \\
& $(6.079)$ & $(5.662)$ & $(5.574)$ & $(5.554)$ & $(5.515)$ \\
Individual & NO & YES & YES & YES & YES \\
History of the marriage & NO & NO & YES & YES & YES \\
Labor market & NO & NO & NO & YES & YES \\
Type of marriage & NO & NO & NO & NO & YES \\
Observations & 413,780 & 413,780 & 413,780 & 413,780 & 413,780 \\
R-squared & 0.040 & 0.100 & 0.136 & 0.178 & 0.180
\end{tabular}

Notes. The outcome is the amount of money that the father is obliged to provide for child maintenance to the mother (indirect support). Time and Court fixed effects are included in all specifications. Standard errors are corrected to allow the clustering of the residuals at the court level. ${ }^{* *}\left({ }^{*}\right)[+]$ denotes significance at the $1 \%(5 \%)$ [10\%] level. Individual controls include (both for males and females): civil status before the marriage (single, divorced, widowed), age, a dummy for foreign born individuals, nationality, education (dummies for high school and university achievements). History of the marriage controls include: duration of the marriage and number of children. Labor market controls include (both for males and females): labor market status (employed, unemployed, out of the labor force), work status (entrepreneur, self-employed, white-collar, blue-collar), sector of activity (agriculture, services, manufacturing, public sector). Type of marriage controls include: religious weddings and marriage financial agreement (joint or disjoint management of the family wealth). 
Table 6. The Impact of Joint Custody on Alimony (Outcome: B1)

\begin{tabular}{cccccc}
\hline & $(1)$ & $(2)$ & $(3)$ & $(4)$ & $(5)$ \\
\hline POST $(\alpha 1)$ & $-0.015^{* *}$ & $-0.018^{* *}$ & $-0.019^{* *}$ & $-0.021^{* *}$ & $-0.021^{* *}$ \\
& $(0.004)$ & $(0.004)$ & $(0.004)$ & $(0.004)$ & $(0.004)$ \\
TREAT $(\alpha 2)$ & $0.044^{* *}$ & $0.065^{* *}$ & $0.033^{* *}$ & $0.042^{* *}$ & $0.041^{* *}$ \\
POST*TREAT $(\alpha 3)$ & $(0.004)$ & $(0.005)$ & $(0.004)$ & $(0.003)$ & $(0.003)$ \\
& $0.013^{* *}$ & $0.018^{* *}$ & $0.018^{* *}$ & $0.021^{* *}$ & $0.021^{* *}$ \\
Individual & $(0.004)$ & $(0.004)$ & $(0.004)$ & $(0.004)$ & $(0.004)$ \\
History of the marriage & NO & YES & YES & YES & YES \\
Labor market & NO & NO & YES & YES & YES \\
Type of marriage & NO & NO & NO & YES & YES \\
Observations & & NO & NO & NO & YES \\
R-squared & 869,636 & 869,636 & 869,636 & 869,636 & 869,636 \\
& 0.035 & 0.072 & 0.075 & 0.180 & 0.180
\end{tabular}

Notes. The outcome is the probability that the husband is obliged to provide a sum of money for the maintenance of the wife. Time and Court fixed effects are included in all specifications. Standard errors are corrected to allow the clustering of the residuals at the court level. ${ }^{* *}\left({ }^{*}\right)[+]$ denotes significance at the $1 \%(5 \%)[10 \%]$ level. Individual controls include (both for males and females): civil status before the marriage (single, divorced, widowed), age, a dummy for foreign born individuals, nationality, education (dummies for high school and university achievements). History of the marriage controls include: duration of the marriage and number of children. Labor market controls include (both for males and females): labor market status (employed, unemployed, out of the labor force), work status (entrepreneur, self-employed, white-collar, blue-collar), sector of activity (agriculture, services, manufacturing, public sector). Type of marriage controls include: religious weddings and marriage financial agreement (joint or disjoint management of the family wealth).

Table 7. The Impact of Joint Custody on Money for Alimony (Outcome: B2)

\begin{tabular}{|c|c|c|c|c|c|}
\hline & (1) & $(2)$ & (3) & (4) & (5) \\
\hline POST ( $\alpha 1)$ & $\begin{array}{l}57.487^{\star \star} \\
(14.767)\end{array}$ & $\begin{array}{l}53.720^{\star *} \\
(13.987)\end{array}$ & $\begin{array}{l}53.992^{\star *} \\
(14.025)\end{array}$ & $\begin{array}{l}51.669^{* *} \\
(14.304)\end{array}$ & $\begin{array}{l}53.711^{* *} \\
(14.382)\end{array}$ \\
\hline TREAT $(\alpha 2)$ & $\begin{array}{c}-108.953^{* *} \\
(7.927)\end{array}$ & $\begin{array}{c}-92.798^{* *} \\
(8.059)\end{array}$ & $\begin{array}{c}-127.017^{\star *} \\
(11.030)\end{array}$ & $\begin{array}{c}-139.814^{\star *} \\
(11.361)\end{array}$ & $\begin{array}{c}-137.931^{* *} \\
(11.361)\end{array}$ \\
\hline $\mathrm{POST}^{\star} \mathrm{TREAT}(\alpha 3)$ & $\begin{array}{c}-18.078 \\
(11.966)\end{array}$ & $\begin{array}{c}-17.769 \\
(11.361)\end{array}$ & $\begin{array}{l}-18.204 \\
(11.312)\end{array}$ & $\begin{array}{c}-19.402+ \\
(11.688)\end{array}$ & $\begin{array}{c}-20.817+ \\
(11.727)\end{array}$ \\
\hline Individual & NO & YES & YES & YES & YES \\
\hline $\begin{array}{l}\text { History of the } \\
\text { marriage }\end{array}$ & NO & NO & YES & YES & YES \\
\hline Labor market & NO & NO & NO & YES & YES \\
\hline Type of marriage & NO & NO & NO & NO & YES \\
\hline Observations & 184,337 & 184,337 & 184,337 & 184,337 & 184,337 \\
\hline R-squared & 0.035 & 0.071 & 0.071 & 0.095 & 0.096 \\
\hline
\end{tabular}

Notes. The outcome is the amount of money that the husband is obliged to provide for the maintenance of the wife. Time and Court fixed effects are included in all specifications. Standard errors are corrected to allow the clustering of the residuals at the court level. ${ }^{* \star}\left({ }^{*}\right)[+]$ denotes significance at the $1 \%(5 \%)[10 \%]$ level. Individual controls include (both for males and females): civil status before the marriage (single, divorced, widowed), age, a dummy for foreign born individuals, nationality, education (dummies for high school and university achievements). History of the marriage controls include: duration of the marriage and number of children. Labor market controls include (both for males and females): labor market status (employed, unemployed, out of the labor force), work status (entrepreneur, self-employed, white-collar, blue-collar), sector of activity (agriculture, services, manufacturing, public sector). Type of marriage controls include: religious weddings and marriage financial agreement (joint or disjoint management of the family wealth). 
Table 8. The Impact of Joint Custody on Judicial Outcomes: Giudiziali vs Consensuali

\begin{tabular}{|c|c|c|c|c|c|c|c|c|c|c|c|c|}
\hline 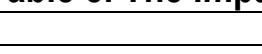 & $(1)$ & $(2)$ & (3) & (4) & $(5)$ & (6) & (7) & (8) & (9) & (10) & (11) & (12) \\
\hline Outcome: & \multicolumn{2}{|c|}{ Sole custody to mother } & \multicolumn{2}{|c|}{ Family house to mother } & \multicolumn{2}{|c|}{ Indirect child support } & \multicolumn{2}{|c|}{ Money for indirect child support } & \multicolumn{2}{|c|}{ Alimony } & \multicolumn{2}{|c|}{ Money for alimony } \\
\hline Type of separation: & Giudiz. & Cons. & Giudiz. & Cons. & Giudiz. & Cons. & Giudiz. & Cons. & Giudiz. & Cons. & Giudiz. & Cons. \\
\hline POST ( $\alpha 1)$ & $\begin{array}{c}-0.115^{* *} \\
(0.018)\end{array}$ & $\begin{array}{c}-0.259^{* *} \\
(0.013)\end{array}$ & & & $\begin{array}{c}-0.024^{* *} \\
(0.009)\end{array}$ & $\begin{array}{c}-0.029^{* *} \\
(0.004)\end{array}$ & $\begin{array}{l}32.026^{*} \\
(12.720)\end{array}$ & $\begin{array}{l}-4.416 \\
(6.132)\end{array}$ & & & & \\
\hline $\operatorname{POST}^{*} T R E A T(\alpha 3)$ & & & $\begin{array}{l}0.032+ \\
(0.019)\end{array}$ & $\begin{array}{c}0.006 \\
(0.004)\end{array}$ & & & & & $\begin{array}{l}0.025^{\star *} \\
(0.009)\end{array}$ & $\begin{array}{l}0.020^{* *} \\
(0.004)\end{array}$ & $\begin{array}{l}-12.717 \\
(18.778)\end{array}$ & $\begin{array}{l}-22.927+ \\
(12.471)\end{array}$ \\
\hline Individual & YES & YES & YES & YES & YES & YES & YES & YES & YES & YES & YES & YES \\
\hline History of the marriage & YES & YES & YES & YES & YES & YES & YES & YES & YES & YES & YES & YES \\
\hline Labor market & YES & YES & YES & YES & YES & YES & YES & YES & YES & YES & YES & YES \\
\hline Type of marriage & YES & YES & YES & YES & YES & YES & YES & YES & YES & YES & YES & YES \\
\hline $\begin{array}{c}\text { Observations } \\
\text { R-squared }\end{array}$ & $\begin{array}{c}59,520 \\
0.315\end{array}$ & $\begin{array}{c}388,453 \\
0.469\end{array}$ & $\begin{array}{c}114,264 \\
0.128\end{array}$ & $\begin{array}{c}755,372 \\
0.112\end{array}$ & $\begin{array}{c}114,264 \\
0.486\end{array}$ & $\begin{array}{c}755,372 \\
0.519\end{array}$ & $\begin{array}{c}59,253 \\
0.175\end{array}$ & $\begin{array}{c}354,527 \\
0.184\end{array}$ & $\begin{array}{c}114,264 \\
0.158\end{array}$ & $\begin{array}{c}755,372 \\
0.184\end{array}$ & $\begin{array}{c}33,333 \\
0.113\end{array}$ & $\begin{array}{c}151,004 \\
0.097\end{array}$ \\
\hline
\end{tabular}

Notes. For each outcome, the table reports the estimates obtained by splitting the sample between separations by mutual consent (consensuali) and those where the judge is requested to take a decision as no previous agreement has been reached (giudiziali). Time and Court fixed effects are included in all specifications. Standard errors are corrected to allow the clustering of the residuals at the court level. ${ }^{* *}\left({ }^{*}\right)[+]$ denotes significance at the $1 \%(5 \%)[10 \%]$ level. Individual controls include (both for males and females): civil status before the marriage (single, divorced, widowed), age, a dummy for foreign born individuals, nationality, education (dummies for high school and university achievements). History of the marriage controls include: duration of the marriage and number of children. Labor market controls include (both for males and females): labor market status (employed, unemployed, out of the labor force), work status (entrepreneur, self-employed, white-collar, blue-collar), sector of activity (agriculture, services, manufacturing, public sector). Type of marriage controls include: religious weddings and marriage financial agreement (joint or disjoint management of the family wealth). 
Table 9. The Impact of Joint Custody on Separation with No Agreement (Outcome: C1)

\begin{tabular}{|c|c|c|c|c|c|}
\hline & (1) & $(2)$ & (3) & (4) & $(5)$ \\
\hline POST ( $\alpha 1)$ & $\begin{array}{c}0.008 \\
(0.007)\end{array}$ & $\begin{array}{c}0.006 \\
(0.006)\end{array}$ & $\begin{array}{c}0.006 \\
(0.006)\end{array}$ & $\begin{array}{c}0.006 \\
(0.006)\end{array}$ & $\begin{array}{c}0.005 \\
(0.006)\end{array}$ \\
\hline TREAT $(\alpha 2)$ & $\begin{array}{l}0.013^{* *} \\
(0.004)\end{array}$ & $\begin{array}{l}0.025^{* *} \\
(0.004)\end{array}$ & $\begin{array}{l}0.020^{* *} \\
(0.005)\end{array}$ & $\begin{array}{l}0.020^{* *} \\
(0.004)\end{array}$ & $\begin{array}{l}0.020^{* *} \\
(0.005)\end{array}$ \\
\hline $\mathrm{POST}^{\star} \mathrm{TREAT}(\alpha 3)$ & $\begin{array}{l}0.007^{*} \\
(0.003)\end{array}$ & $\begin{array}{l}0.011^{* *} \\
(0.003)\end{array}$ & $\begin{array}{l}0.010^{* *} \\
(0.003)\end{array}$ & $\begin{array}{l}0.012^{* *} \\
(0.003)\end{array}$ & $\begin{array}{l}0.012^{* *} \\
(0.003)\end{array}$ \\
\hline Individual & NO & YES & YES & YES & YES \\
\hline History of the marriage & NO & NO & YES & YES & YES \\
\hline Labor market & NO & NO & NO & YES & YES \\
\hline Type of marriage & NO & NO & NO & NO & YES \\
\hline $\begin{array}{c}\text { Observations } \\
\text { R-squared }\end{array}$ & $\begin{array}{c}869,636 \\
0.037\end{array}$ & $\begin{array}{c}869,636 \\
0.062\end{array}$ & $\begin{array}{c}869,636 \\
0.062\end{array}$ & $\begin{array}{c}869,636 \\
0.068\end{array}$ & $\begin{array}{c}869,636 \\
0.068\end{array}$ \\
\hline
\end{tabular}

Notes. The outcome is the share of separation for which there is no mutual consent (separazioni giudiziali). Time and Court fixed effects are included in all specifications. Standard errors are corrected to allow clustering at the court level. ${ }^{* \star}\left({ }^{*}\right)[+]$ denotes significance at the $1 \%(5 \%)[10 \%]$ level. Individual controls include (both for males and females): civil status before the marriage (single, divorced, widowed), age, a dummy for foreign born individuals, nationality, education (dummies for high school and university achievements). History of the marriage controls include: duration of the marriage and number of children. Labor market controls include (both for males and females): labor market status (employed, unemployed, out of the labor force), work status (entrepreneur, self-employed, white-collar, blue-collar), sector of activity (agriculture, services, manufacturing, public sector). Type of marriage controls include: religious weddings and marriage financial agreement (joint or disjoint management of the family wealth).

Table 10. The Impact of Joint Custody on Judicial Efficiency (Outcome: C2)

\begin{tabular}{|c|c|c|c|c|c|}
\hline & (1) & (2) & (3) & (4) & (5) \\
\hline POST ( $\alpha 1)$ & $\begin{array}{l}-2.238 \\
(5.565)\end{array}$ & $\begin{array}{l}-4.032 \\
(5.310)\end{array}$ & $\begin{array}{c}-4.034 \\
(5.315)\end{array}$ & $\begin{array}{l}-4.436 \\
(5.304)\end{array}$ & $\begin{array}{l}-4.682 \\
(5.258)\end{array}$ \\
\hline TREAT $(\alpha 2)$ & $\begin{array}{c}16.989^{* *} \\
(3.620)\end{array}$ & $\begin{array}{c}30.394^{* *} \\
(3.759)\end{array}$ & $\begin{array}{c}31.775^{\star *} \\
(4.416)\end{array}$ & $\begin{array}{c}31.457^{* *} \\
(4.207)\end{array}$ & $\begin{array}{c}30.813^{* *} \\
(4.327)\end{array}$ \\
\hline $\mathrm{POST}^{*} \mathrm{TREAT}(\alpha 3)$ & $\begin{array}{c}11.480 \text { ** } \\
(3.351)\end{array}$ & $\begin{array}{c}15.078^{* *} \\
(3.390)\end{array}$ & $\begin{array}{c}15.092^{* *} \\
(3.406)\end{array}$ & $\begin{array}{c}15.704^{* *} \\
(3.412)\end{array}$ & $\begin{array}{c}15.970 \text { ** } \\
(3.463)\end{array}$ \\
\hline Individual & NO & YES & YES & YES & YES \\
\hline History of the marriage & NO & NO & YES & YES & YES \\
\hline Labor market & NO & NO & NO & YES & YES \\
\hline Type of marriage & NO & NO & NO & NO & YES \\
\hline Observations & 869,636 & 869,636 & 869,636 & 869,636 & 869,636 \\
\hline R-squared & 0.058 & 0.080 & 0.080 & 0.086 & 0.086 \\
\hline
\end{tabular}

\footnotetext{
Notes. The outcome is the number of days necessary for a judge to conclude a trial. Time and Court fixed effects are included in all specifications. Standard errors are corrected to allow the clustering of the residuals at the court level. ${ }^{* *}\left({ }^{*}\right)[+]$ denotes significance at the $1 \%(5 \%)[10 \%]$ level. Individual controls include (both for males and females): civil status before the marriage (single, divorced, widowed), age, a dummy for foreign born individuals, nationality, education (dummies for high school and university achievements). History of the marriage controls include: duration of the marriage and number of children. Labor market controls include (both for males and females): labor market status (employed, unemployed, out of the labor force), work status (entrepreneur, self-employed, white-collar, blue-collar), sector of activity (agriculture, services, manufacturing, public sector). Type of marriage controls include: religious weddings and marriage financial agreement (joint or disjoint management of the family wealth).
} 
Table 11. The Impact of Joint Custody on the Gender of the Applicant (Outcome c.3)

\begin{tabular}{cccccc}
\hline & $(1)$ & $(2)$ & $(3)$ & $(4)$ & $(5)$ \\
\hline POST $(\alpha 1)$ & -0.006 & -0.008 & -0.008 & -0.009 & $-0.010+$ \\
TREAT $(\alpha 2)$ & $(0.006)$ & $(0.006)$ & $(0.006)$ & $(0.006)$ & $(0.006)$ \\
& $0.062^{* *}$ & $0.072^{* *}$ & $0.056^{* *}$ & $0.057^{* *}$ & $0.056^{* *}$ \\
POST TREAT $(\alpha 3)$ & $(0.003)$ & $(0.003)$ & $(0.005)$ & $(0.004)$ & $(0.005)$ \\
& $0.010^{*}$ & $0.014^{* *}$ & $0.014^{* *}$ & $0.015^{* *}$ & $0.015^{* *}$ \\
Individual & $(0.004)$ & $(0.004)$ & $(0.004)$ & $(0.004)$ & $(0.004)$ \\
History of the marriage & NO & YES & YES & YES & YES \\
Labor market & NO & NO & YES & YES & YES \\
Type of marriage & NO & NO & NO & YES & YES \\
Observations & NO & NO & NO & NO & YES \\
R-squared & & & & 869,636 & 869,636 \\
& & & & & $0.059,636$ \\
\end{tabular}

Notes. The outcome is the fraction of women that fill the application for requesting a separation. Time and Court fixed effects are included in all specifications. Standard errors are corrected to allow the clustering of the residuals at the court level. ${ }^{* *}\left({ }^{*}\right)[+]$ denotes significance at the $1 \%(5 \%)[10 \%]$ level. Individual controls include (both for males and females): civil status before the marriage (single, divorced, widowed), age, a dummy for foreign born individuals, nationality, education (dummies for high school and university achievements). History of the marriage controls include: duration of the marriage and number of children. Labor market controls include (both for males and females): labor market status (employed, unemployed, out of the labor force), work status (entrepreneur, self-employed, white-collar, blue-collar), sector of activity (agriculture, services, manufacturing, public sector). Type of marriage controls include: religious weddings and marriage financial agreement (joint or disjoint management of the family wealth). 
Table 12. Differentiating court-level trends away

\begin{tabular}{|c|c|c|c|c|c|c|c|c|c|}
\hline & $(1)$ & (2) & (3) & (4) & $(5)$ & $(6)$ & (7) & $(8)$ & (9) \\
\hline Outcome: & $\begin{array}{l}\text { Sole custody to } \\
\text { mother }\end{array}$ & $\begin{array}{c}\text { Family house to } \\
\text { mother }\end{array}$ & $\begin{array}{l}\text { Indirect child } \\
\text { support }\end{array}$ & $\begin{array}{l}\text { Money for indirect child } \\
\text { support }\end{array}$ & Alimony & $\begin{array}{l}\text { Money for } \\
\text { alimony }\end{array}$ & $\begin{array}{l}\text { Separation with } \\
\text { No Agreement }\end{array}$ & $\begin{array}{l}\text { Judicial } \\
\text { Efficiency }\end{array}$ & $\begin{array}{l}\text { Gender of the } \\
\text { Applicant }\end{array}$ \\
\hline POST ( $\alpha 1)$ & $\begin{array}{c}-0.044^{* *} \\
(0.015)\end{array}$ & & $\begin{array}{c}-0.012+ \\
(0.007)\end{array}$ & $\begin{array}{c}4.554 \\
(11.618)\end{array}$ & & & & & \\
\hline POST $^{*} T R E A T(\alpha 3)$ & & $\begin{array}{l}0.009^{* *} \\
(0.004)\end{array}$ & & & $\begin{array}{l}0.021^{* *} \\
(0.004)\end{array}$ & $\begin{array}{l}-19.290 \\
(11.886)\end{array}$ & $\begin{array}{l}0.013^{* *} \\
(0.003)\end{array}$ & $\begin{array}{l}16.247^{* *} \\
(3.252)\end{array}$ & $\begin{array}{l}0.014^{* *} \\
(0.004)\end{array}$ \\
\hline Individual & YES & YES & YES & YES & YES & YES & YES & YES & YES \\
\hline History of the marriage & YES & YES & YES & YES & YES & YES & YES & YES & YES \\
\hline Labor market & YES & YES & YES & YES & YES & YES & YES & YES & YES \\
\hline Type of marriage & YES & YES & YES & YES & YES & YES & YES & YES & YES \\
\hline Observations & 447,973 & 869,636 & 869,636 & 433,449 & 869,636 & 187,437 & 869,636 & 869,636 & 869,636 \\
\hline R-squared & 0.447 & 0.111 & 0.515 & 0.185 & 0.183 & 0.099 & 0.072 & 0.091 & 0.055 \\
\hline
\end{tabular}

Notes. Time, Court and Time by Court fixed effects are included in all specifications. Standard errors are corrected to allow the clustering of the residuals at the court level. **** $\left.{ }^{*}+\right]$ denotes significance at the $1 \%(5 \%)[10 \%]$ level. Individual controls include (both for males and females): civil status before the marriage (single, divorced, widowed), age, a dummy for foreign born individuals, nationality, education (dummies for high school and university force), work status (entrepreneur, self-employed, white-collar, blue-collar), sector of activity (agriculture, services, manufacturing, public sector). Type of marriage controls include: religious weddings and marriage financial agreement (joint or disjoint management of the family wealth). 
Appendix I. Descriptive statistics for the control variables

\begin{tabular}{|c|c|c|c|c|}
\hline & \multirow{2}{*}{\multicolumn{2}{|c|}{ Treated }} & (3) & (4) \\
\hline & & & \multicolumn{2}{|c|}{ Controls } \\
\hline & Before & After & Before & After \\
\hline \multicolumn{5}{|c|}{ Individual controls } \\
\hline husband marital status before marriage: not single & $0,01(0,11)$ & $0,02(0,13)$ & $0,02(0,14)$ & $0,04(0,19)$ \\
\hline wife marital status before marriage: not single & $0,01(0,09)$ & $0,01(0,12)$ & $0,02(0,14)$ & $0,04(0,19)$ \\
\hline age of husband & $41,57(7,53)$ & $43,43(7,57)$ & $44,53(12,22)$ & $47,06(12,47)$ \\
\hline age of wife & $38,33(7,09)$ & $40,22(7,16)$ & $41,24(12,02)$ & $43,74(12,23)$ \\
\hline husband foreign born & $0,04(0,19)$ & $0,04(0,19)$ & $0,04(0,2)$ & $0,05(0,21)$ \\
\hline wife foreign born & $0,06(0,23)$ & $0,06(0,23)$ & $0,08(0,28)$ & $0,1(0,29)$ \\
\hline husband not Italian nationality & $0,01(0,12)$ & $0,01(0,11)$ & $0,02(0,13)$ & $0,02(0,13)$ \\
\hline wife not Italian nationality & $0,02(0,14)$ & $0,02(0,13)$ & $0,04(0,2)$ & $0,04(0,19)$ \\
\hline husband w/ university education & $0,12(0,32)$ & $0,12(0,33)$ & $0,12(0,32)$ & $0,13(0,33)$ \\
\hline husband w/ high school diploma & $0,38(0,49)$ & $0,41(0,49)$ & $0,38(0,49)$ & $0,39(0,49)$ \\
\hline husband w/low education & $0,5(0,5)$ & $0,47(0,5)$ & $0,5(0,5)$ & $0,49(0,5)$ \\
\hline wife w/ university education & $0,11(0,31)$ & $0,13(0,34)$ & $0,12(0,32)$ & $0,15(0,36)$ \\
\hline wife w/ high school diploma & $0,43(0,5)$ & $0,46(0,5)$ & $0,42(0,49)$ & $0,42(0,49)$ \\
\hline wife w/ low education & $0,46(0,5)$ & $0,4(0,49)$ & $0,46(0,5)$ & $0,43(0,5)$ \\
\hline \multicolumn{5}{|c|}{ History of the marriage } \\
\hline duration of marriage & $14,07(7,02)$ & $14,94(7,3)$ & $15,07(12,7)$ & $16,55(13,54)$ \\
\hline number of kids & $1,49(0,64)$ & $1,52(0,65)$ & $0,01(0,14)$ & $0,01(0,11)$ \\
\hline \multicolumn{5}{|c|}{ Labor market } \\
\hline husband employed & $0,92(0,26)$ & $0,89(0,31)$ & $0,82(0,39)$ & $0,75(0,43)$ \\
\hline husband unemployed & $0,04(0,2)$ & $0,06(0,24)$ & $0,04(0,19)$ & $0,07(0,25)$ \\
\hline husband retired & $0,02(0,15)$ & $0,02(0,14)$ & $0,13(0,33)$ & $0,14(0,34)$ \\
\hline husband - other condition & $0,01(0,1)$ & $0,02(0,14)$ & $0,02(0,13)$ & $0,05(0,21)$ \\
\hline wife employed & $0,67(0,47)$ & $0,68(0,47)$ & $0,67(0,47)$ & $0,63(0,48)$ \\
\hline wife unemployed & $0,05(0,21)$ & $0,08(0,27)$ & $0,05(0,21)$ & $0,08(0,26)$ \\
\hline house wife & $0,25(0,43)$ & $0,2(0,4)$ & $0,21(0,41)$ & $0,19(0,4)$ \\
\hline wife retired & $0,01(0,09)$ & $0,01(0,09)$ & $0,05(0,22)$ & $0,06(0,23)$ \\
\hline wife - other condition & $0,02(0,15)$ & $0,03(0,18)$ & $0,03(0,16)$ & $0,05(0,21)$ \\
\hline husband entrepreneur & $0,15(0,35)$ & $0,17(0,37)$ & $0,14(0,34)$ & $0,14(0,35)$ \\
\hline husband self-employed & $0,18(0,38)$ & $0,15(0,36)$ & $0,15(0,36)$ & $0,13(0,33)$ \\
\hline husband white collar & $0,28(0,45)$ & $0,27(0,44)$ & $0,26(0,44)$ & $0,23(0,42)$ \\
\hline husband blue collar & $0,32(0,47)$ & $0,33(0,47)$ & $0,28(0,45)$ & $0,28(0,45)$ \\
\hline wife entrepreneur & $0,05(0,23)$ & $0,07(0,25)$ & $0,06(0,24)$ & $0,07(0,25)$ \\
\hline wife self-employed & $0,07(0,25)$ & $0,06(0,24)$ & $0,07(0,26)$ & $0,06(0,23)$ \\
\hline wife white collar & $0,34(0,47)$ & $0,36(0,48)$ & $0,34(0,47)$ & $0,33(0,47)$ \\
\hline wife blue collar & $0,24(0,43)$ & $0,25(0,43)$ & $0,22(0,41)$ & $0,22(0,42)$ \\
\hline husband agriculture & $0,03(0,16)$ & $0,03(0,17)$ & $0,02(0,15)$ & $0,02(0,16)$ \\
\hline husband manufacturing & $0,24(0,43)$ & $0,23(0,42)$ & $0,23(0,42)$ & $0,2(0,4)$ \\
\hline husband services & $0,23(0,42)$ & $0,22(0,41)$ & $0,21(0,41)$ & $0,19(0,39)$ \\
\hline husband public sector & $0,19(0,4)$ & $0,17(0,38)$ & $0,16(0,36)$ & $0,13(0,34)$ \\
\hline husband other & $0,27(0,44)$ & $0,31(0,46)$ & $0,24(0,43)$ & $0,27(0,44)$ \\
\hline wife agriculture & $0,01(0,11)$ & $0,01(0,12)$ & $0,01(0,1)$ & $0,01(0,11)$ \\
\hline wife manufacturing & $0,12(0,33)$ & $0,11(0,31)$ & $0,13(0,34)$ & $0,1(0,31)$ \\
\hline wife services & $0,18(0,39)$ & $0,21(0,41)$ & $0,2(0,4)$ & $0,21(0,4)$ \\
\hline wife public sector & $0,21(0,41)$ & $0,2(0,4)$ & $0,18(0,38)$ & $0,15(0,36)$ \\
\hline wife other & $0,19(0,39)$ & $0,23(0,42)$ & $0,19(0,4)$ & $0,23(0,42)$ \\
\hline \multicolumn{5}{|c|}{ Type of marriage } \\
\hline not religious wedding & $0,24(0,42)$ & $0,28(0,45)$ & $0,28(0,45)$ & $0,35(0,48)$ \\
\hline disjoint management of the family wealth & $0,4(0,49)$ & $0,46(0,5)$ & $0,47(0,5)$ & $0,51(0,5)$ \\
\hline Number of observations & 273458 & 221875 & 207074 & 167229 \\
\hline
\end{tabular}

